\title{
Land Reform and Sustainable Development
}

\author{
James K. Boyce, Peter Rosset, and Elizabeth A. Stanton *
}

June 2005

\begin{abstract}
Land reform - the reallocation of rights to establish a more equitable distribution of farmland can be a powerful strategy for promoting both economic development and environmental quality. This paper surveys land reform strategies, illustrated by the postwar reforms in East Asia and the 'bottom- up' land reform today being led by Brazil's Landless Workers' Movement. Land reform can reduce rural poverty not only by channeling a larger slice of the agricultural-income pie to low-income households, but also by increasing the size of the pie by raising land productivity. Land reform's contribution to poverty reduction can be magnified by spillover effects in the urban economy. With a supportive policy environment, land reform also can foster a transition to sustainable agriculture, due to the environmental comparative advantages of small farms.
\end{abstract}

\footnotetext{
* James K. Boyce is professor of economics at the University of Massachusetts, Amherst, and director of PERI"s program on development, peacebuilding, and the environment. Peter Rosset is co-coordinator of the Land Research Action Network (www.landaction.org). Elizabeth Stanton is a doctoral student at the University of Massachusetts, Amherst. This paper was prepared for PERI's Natural Assets Project (http://www.umass.edu/peri/programs/development/naturalassets.htm).
} 


\section{Introduction}

In agricultural economies, land is the single most important asset. With access to arable land, rural people at a minimum can feed themselves and their families. Yet ironically, world hunger is concentrated in the countryside. The United Nations Food and Agriculture Organization (FAO 2004, 25) reports that land-poor and landless households in rural areas account for 80 percent of the people who are chronically hungry in the world today.

Land reform - here defined as the reallocation of rights to establish a more equitable distribution of farmland - can be a powerful strategy for promoting both economic development and environmental quality. Across the globe, small-scale farmers consistently tend to grow more output per acre than large farms. At the same time, when small family farmers hold secure land rights, they tend to be better environmental stewards, protecting and enhancing soil fertility, water quality, and biodiversity. For both reasons, democratizing access to land can be the cornerstone for sustainable rural development.

This chapter provides an overview of land reform as a natural asset-building strategy. First we sketch the wide variety of changes in agrarian structure that fall under the rubric of 'land reform.' To illustrate we review the experiences of China, Japan, Korea, and Taiwan after World War II, where land reforms helped to set the stage for rapid economic growth. We then describe of one of the most vibrant land reform movements of the present day: the Landless Workers' Movement of Brazil. Drawing on these and other examples, we then discuss the effects of land reform on both poverty reduction and environmental quality.

\section{Varieties of Land Reform}

Land reform comes in many shapes and sizes. In this chapter, we are concerned with the redistribution of rights from relatively wealthy landowners, who cultivate primarily by means of hired laborer or tenant farmers, to relatively poor people who cultivate primarily with their own family labor. Even then, land reforms can and do vary in a number of dimensions:

- Rights: Property rights are a 'bundle of sticks,' not all of which necessarily belong to the same party. ${ }^{1}$ For example, a tenant farmer may hold an 'occupancy right' to cultivate the land in return for payment of rent, while the landlord has the right to sell the land. Land reforms may redistribute certain sticks in the bundle but not others. Reforms that strengthen the rights of tenants, for example, by prohibiting arbitrary evictions or putting a ceiling on rents, are less far-reaching than 'land-to-the-tiller' reforms that expropriate landlords and transfer land titles to the tenants.

- Security: Property rights are never perfectly secure. In many times and places, small farmers have been dispossessed by legal chicanery or outright force; in the words of American folksinger Woody Guthrie, 'Some rob you with a sixgun, some with a fountain pen.' Land reforms can be reversed over time by these or more 'normal' processes of land concentration, particularly if large landowners enjoy preferential access to inputs, subsidies, and other advantages. ${ }^{2}$ Some land reforms have kept such processes in check by distributing non- 
saleable use rights to farmers, while the community or the state retains title to the land. After the 1910 revolution in Mexico, for example, ownership of roughly half the country's farmland was vested in communities called ejidos, in which families hold use rights to individual plots as long as they continue to till them. ${ }^{3}$

- Structure: The new agrarian structure established by a land reform can be based on family farms, small-scale cooperatives, large-scale collectives, or state farms. Strategies shift over time. For example, the Chinese revolution initially redistributed land to individual families, then organized them into cooperatives and later into large communes; but a generation later, use rights were reallocated to households. Similarly, in Nicaragua the Sandinista government initially created state farms on large holdings expropriated from the former dictator and other estate owners; in an effort to consolidate their political base, they later experimented with cooperatives and issued individual titles to peasants. ${ }^{4}$

- Egalitarianism: The degree to which land reform programs yield a more egalitarian agrarian structure is, well, a matter of degree. During British rule in India, for example, a series of tenancy reforms in Bengal redistributed rights from large landlords to the upper stratum of the peasantry, while doing little to expand the land rights of the poor. ${ }^{5}$ The postwar land reforms in East Asia, described in the next section, had much stronger egalitarian impacts.

- Gender: Land reform can also affect disparities between men and women. In El Salvador, for example, a U.S.-backed reform in the 1980s that transferred titles from landlord to tenants actually had the effect of worsening women's (already inferior) position: women comprised only 10 percent of the beneficiaries, but they accounted for 36 percent of those whose lands were expropriated, the latter being mostly 'elderly widows and single women who did not work the land directly themselves, but rather sharecropped it or rented it out' (Deere and León 2001, 98). In contrast, Colombia's land redistribution program in the late 1990s improved women's land rights by mandating joint titles for couples instead of exclusive titles for male household 'heads.' Moreover, women in Colombia received nearly one-third of the land titles that were distributed to individuals rather than couples (Deere and León 2001, 195-197).

- Compensation: Land reforms also vary in their treatment of those whose land rights are redistributed to others. In some cases, as in the Chinese revolution, land simply is confiscated without compensation. In others, as in Guatemala's 1954 land reform that was aborted quickly by a CIA-backed coup, large landowners are compensated at a fraction of the market value of the land (in this case, compensation was to be based on the value that the landowner had declared for tax purposes, which usually was well below the land's market price). ${ }^{6}$ In still other cases, as in Guatemala after the 1996 Peace Accord, former landowners receive full (or even inflated) compensation from the government, and beneficiaries are supposed to repay part or all of the cost in future years. As a general rule, successful redistributive land reforms have featured what Griffin, Khan, and Ickowitz $(2002,279)$ term a 'high degree of land confiscation.'

- Macroeconomic environment: While land reform can make a tremendous difference in the lives of the rural poor, it is not a panacea for rural poverty. In the absence of broader 
macroeconomic policies that support agriculture in general, and small-scale producers in particular, land reform alone will not bring substantial income gains to the poor. Indeed, if the macroeconomic context is quite adverse to agriculture - for example, if exchange rate overvaluation and trade policies make agricultural imports so cheap that local growers cannot compete - then to encourage the poor to seek to earn a living in farming is to lure them into debt and penury. For this reason, Acevedo (1996, 209) observed that in El Salvador in the 1990s, 'a small farm (particularly one encumbered by debt for its acquisition) and access to agricultural credit is an economic curse to be wished only on one's worst enemy., 7

- Process: A genuine land reform requires a profound social transformation. The processes by which land reform has come about have included 'top-down' initiatives like that of General Douglas MacArthur's administration in postwar Japan, 'bottom- up' popular movements like today's Landless Workers' Movement in Brazil, and combinations of the two like the Chinese revolution. But a feature that all successful land reforms share in common is 'a transformation in the balance of power within the rural community and in society at large' (Sobhan 1993, 7). Attempts to implement land reforms without changing the balance of power - what Sobhan calls 'inegalitarian reforms without social transition' - at best yield only modest results.

\section{Land Reform and the East Asian 'Miracle'}

Despite wide differences in their political regimes and economic policies, the East Asian countries that emerged in the second half of the $20^{\text {th }}$ century as the world's fastest-growing economies - China, Japan, South Korea, and Taiwan - had one thing in common: all implemented highly egalitarian land reforms after World War II. Land reform not only helped to reduce rural poverty and unleash agricultural growth, but also helped to lay the social foundation for rapid industrialization.

In China, the Agrarian Reform Law of 1950 institutionalized the land-to-the-tiller redistributive reforms that were begun in communist-controlled territories during the revolution. Landlords whom the Chinese defined as the rural 'gentry' who did not work in the fields - were expropriated, and sometimes killed, and their properties were transferred to landless and poor peasants. Individual peasant proprietors, including these land reform beneficiaries, were free to buy, sell, and rent land. According to Meisner (1986, p. 140), in the early years of the revolution 'the traditional Chinese ideal of a system of more or less equal family-owned and -operated farms... was probably more fully realized than it ever had been in China's long history.' The Chinese Communist Party initially advocated a gradual, voluntary transition from individual farming to collective farming. Starting in 1955, however, the party embraced a more aggressive collectivization strategy with the aims of increasing agricultural output, extracting bigger surpluses for industrial investment, and heading off the reemergence of inequalities in the countryside. This culminated in the establishment of 'people's communes,' each of which comprised roughly 5,000 households. The collectivization strategy proved disastrous: it contributed to what has been termed 'the largest famine in human history' in 1959 to 1961, in which millions perished (Smil 1999, 1620). Ultimately the communes were dissolved, in the new 
wave of agrarian reforms begun in the late 1970s. Under the 'household responsibility system,' individual families in China now have the right to till the land, but not to buy or sell it. ${ }^{8}$

In Japan, a far-reaching land reform was initiated after World War II by U.S. occupation authorities under General Douglas MacArthur. American backing for land reform reflected two motives: to dismantle the traditional rural power base of Japanese militarism, and to ward off the appeal of communism by reducing agrarian discontent (Putzel 1992, 69-78). The chief architect of the land reform described it as 'a drastic redistribution of property, income, political power, and social status at the expense of the landlords' (Ladejinsky 1964, 356). The reform put a onehectare ceiling on ownership of tenanted lands, and a three-hectare ceiling on self-cultivated lands. Holdings above these limits were expropriated and redistributed to the tillers of the soil. Former landlords received partial compensation in government bonds. Tenants participated in the local land commissions that implemented the reforms, but most tenants and landlords alike saw it as a top-down transformation imposed 'from the heavens above' (Dore, 1959, 172).

In Taiwan, Chiang Kai-Shek's postwar government similarly sought to win the support of the peasantry and weaken the island's traditional landowning elite, first by imposing a rent ceiling and then by introducing a land-to-the-tiller reform. The latter required landlords to relinquish excess land (defined, in the case of medium-quality land, as anything above three chia, roughly nine acres). The state then sold this land to the tenants. Landowners were compensated with government bonds and shares in public enterprises that had been expropriated from the Japanese. Thanks to the reform, the share of agricultural income accruing to farmers increased from $67 \%$ to $82 \%$, the share received by the government rose from $8 \%$ to $12 \%$, and the share going to landlords and moneylenders fell from $25 \%$ to $6 \% .^{9}$

In South Korea, the U.S. military authorities and the new postwar government also instituted a land-to-the-tiller reform. Prior to this, most farmland was cultivated by tenant farmers, who paid half or more of their crop to Japanese and Korean landlords. The reform transferred ownership rights to former tenants. The ceiling on land ownership was set at three hectares (about 7.5 acres). Korean landlords (but not their Japanese counterparts) received compensation, nominally equal to the 'market price' of the land. In practice, the market price already was deflated by landowner fears of expropriation, and the value of the compensation was further curtailed by stretching payments over time, with no interest or inflation adjustments. The former tenants made in-kind payments (in rice) to the government in return for the land. The government used the income from sale of the rice not only to compensate landlords, but also to invest in rural water supply systems (Jang 2004).

By redistributing rights to the most important rural asset, East Asia's postwar land reforms did much to reduce poverty in the countryside. At the same time, the land reforms helped to set the stage for the rapid industrialization that one day would be hailed as 'the East Asian miracle' (World Bank 1993). Two links between land reform and industrial growth were particularly important. First, farmers' improved economic security meant that they could afford to send their children to school, providing a skilled workforce for industry (Shin, 1998). Second, compared to the landed oligarchies that dominated political life in the pre-reform era, the reforms brought about a more egalitarian order. This helps to explain why government efforts to promote industrialization did not degenerate into a mere pretext for looting state resources and capturing 
policy-generated 'rents,' as so often happened in countries where traditional landed elites retained their grip on power. ${ }^{10}$ Analyzing how and why the state succeeded in promoting industrial growth in South Korea and Taiwan, economist Dani Rodrik (1995, pp. 92-93) concludes that the 'initial advantage' conferred by an egalitarian distribution of wealth and income was 'probably the single most important reason why extensive government intervention could be carried out effectively, without giving rise to rampant rent seeking.' In other words, land reform was one of the keys - arguably the key - to East Asia's economic 'miracle.'

\section{Land Reform from 'Below': Brazil's MST}

Brazil has long had one of the most unequal patterns of land distribution in the world. Since the mid-1980s, however, the country has also given birth to a vibrant land reform movement. As in East Asia, the Brazilian land reform movement strives to redistribute land from the rich to the poor so as to lay the basis for more inclusive economic growth. Unlike the East Asian cases, however, in Brazil the driving impetus for land reform comes not from the state but instead from a popular organization, the Landless Workers' Movement (Movimento dos Trabalhadores Rurais Sem Terra, or MST for short). ${ }^{11}$

The origins of the MST can be traced to Catholic liberation theology, which spread in the Brazilian countryside and urban shantytowns in the 1960s. In the 1970s, the Pastoral Land Commission, organized by the National Council of Catholic Bishops, supported a number of land occupations by landless workers. In the mid-1980s, leaders of these occupations from around the country came together to found the MST.

In Brazilian property law, land ownership is governed by the 'principle of effective use.' This principle, based on moral foundations that go back to Saint Thomas Aquinas and John Locke, provides a legal opening for land occupations. Under the law, landowners who do not use their land productively - thereby failing to fulfill the 'social function' of property - are subject to expropriation (Wright and Wolford 2003, 23-24). This principle was affirmed in the Land Statute passed by Brazil's new military rulers in 1964, and again in the National Agrarian Reform Plan that was passed upon the return to civilian rule in 1985. The latter defines a 'productive farm' as one in which at least $80 \%$ of the acreage is effectively used, environmental and labor standards are respected, and the use of the land is 'of common benefit to landowners and workers' (Deere 2003, 262).

Although farms that do not meet these criteria can be expropriated, in practice Brazilian government authorities 'generally do not act unless direct action forces their hand' (Hammond 1999, 473). This is where the MST plays a crucial role. After identifying an unproductive estate that it considers eligible for expropriation, the MST recruits 200 to 2500 landless families, sometimes from rural areas and sometimes from towns and cities, to carry out an occupation. Over a period of several months, the families are trained and prepared in meetings of 'origin groups' in their places of residence. The occupation is then conducted at a single stroke, mobilizing 'thousands of people overnight, some of them from substantial distances' (Hammond 1999, 474). The landowners typically respond with lawsuits, and sometimes with violence. If they are evicted, the occupiers often erect temporary shelters on nearby state-owned land while 
the litigation proceeds, receiving material support from the MST while they attempt to win legal title to the land.

The MST's strategy is founded on the reality that property rights are never perfectly defined, nor perfectly secure. Instead they are created, and recreated, in an ongoing process of social construction:

Though an occupation is a militant act requiring ideological commitment and a willingness to undertake significant risks, the MST nevertheless assumes and benefits from a public posture embracing moderation and legality. Occupiers demonstrate their willingness to work. They actively mobilise both solidarity (through urban movements including trade unions) and public opinion, claiming that giving the land to those willing to work it could solve the problems of unemployment and food shortage.... The occupation per se is illegal, but they can accurately claim that their aim is to secure enforcement of the law which provides for expropriation of the property, and they are often legally vindicated. (Hammond 1999, 475)

To date, MST-led occupations have enabled some 300,000 Brazilian families (more than a million people) to win legal recognition for more than eight million acres of land reform settlements (Stédile 2004). While this represents only a fraction of the land held in large estates in Brazil, it is an impressive beginning that could mark a historic break from Brazil's highly unequal agrarian structure.

At first, the MST encouraged settlers to undertake collective production on the occupied lands. These efforts often failed. In subsequent years the MST has evolved a flexible system that promotes 'cooperation' in multiple forms, from true collective farming to various kinds of marketing cooperatives that serve individual family farms. A typical settlement of several hundred families may include some groups who farm collectively, as well as several different cooperatives. All families participate together in the political governance of the settlement. ${ }^{12}$

The MST has only recently begun to stress the importance of securing land rights for women. Earlier the organization considered gender issues to be potentially divisive and a diversion from the central issue of class. Under Brazilian law, joint titling to couples is not mandatory, and title to the land often is held by the male 'household head.' At a national seminar in Curitiba in 1997, almost a hundred landless women from across the country debated the role of gender issues in the MST. A gender collective within the MST and a national rural women's organization were subsequently organized. Today the MST has begun to pay more attention to the gender dimension of land reform, prompted by growing awareness that 'the failure to recognize women's land rights is prejudicial to the development and consolidation of the assentamentos (settlements) and thus the movement' (Deere 2003, 284; Martins 2004).

How has 'bottom-up' land reform in Brazil affected the country's environment? In many cases, the large landowners have managed to hang onto their most fertile lands, surrendering those tracts that have been most degraded by past practices. Hence many settlers have realized, as Branford and Rocha $(2002,212)$ report, 'that unless they can return the land to a state of ecological health, the long-term economic viability of their settlements is threatened.' Once they 
win secure land rights, the settlers have a powerful incentive to invest in ecological restoration. Nevertheless, in many cases they instead have imitated the chemical-intensive farming techniques of larger farms. The shift to environmental-friendly farming practices has been slow, but with experience and education, new 'agro-ecological' practices are gaining ground in the MST settlements. These include tree replanting, the use of crop rotations and manures to build soil fertility, and organic farming with some of the produce fetching a price premium in urban markets. ${ }^{13}$ To assist in this transition, the MST has set up an organic seed company, called Bionatur, that sells to settlements around the country.

\section{Land Reform and Poverty Reduction}

By expanding the land rights of the poor, land reform adds to their wealth and thereby reduces asset poverty. This, in turn, helps to reduce income poverty in two ways: first, by increasing the poor's share in the agricultural income pie; and second, by increasing the total size of the pie.

The first effect is straightforward. Assets are stocks of wealth, and these generate flows of income. By redirecting an important flow - the returns to land - into the hands of the poor, progressive land redistribution augments their incomes. At the same time, assets enhance a person's social status and political power. Land reform reduces these 'non-economic' dimensions of poverty, too.

The second effect is more complicated, and less certain. In the short run, land reforms can have 'transaction costs' that reduce agricultural output, particularly if accompanied by political instability that disrupts input supplies or access to markets. Moreover, it may take some time for the beneficiaries to learn how best to manage their new assets. But in the long run, land reforms can increase the size of the agricultural income pie by promoting more labor-intensive farming. In other words, land reform can be a 'win-win' strategy that improves both equity and efficiency.

\section{Farm size and land productivity}

Evidence from around the world demonstrates that small, owner-operated farms typically produce more output per acre than large farms cultivated by means of wage labor or tenants. A recent report on the relationship between farm size and total output in fifteen countries in the global South found that in all cases relatively smaller farms were more productive per unit area, by a factor of two to ten times (Rosset 1999).

This higher output per acre takes four forms:

- Higher cultivation intensity: In any given year, small farms tend to cultivate a bigger percentage of their land than do large farms. In Latin America, in particular, large farms often leave a substantial proportion of their lands uncultivated - a fact that helps to open the legal space for the MST's land occupations in Brazil.

- Higher cropping intensity: Likewise, small farms tend to have a higher cropping intensity; that is, they grow more crops per year on a given piece of land. In Bangladesh, for example, 
$79 \%$ farms of farms of half an acre or less grow two or three crops per year, while only $41 \%$ of farms larger than 25 acres do so. ${ }^{14}$

- Higher-value crop mix: Small farms also tend to grow crops that are higher-value and more labor-intensive than those grown on large farms. The cultivation of vegetables, for example, usually requires much more labor per acre than the cultivation of grains; at the same time, vegetable cultivation yields much greater value per acre.

- Higher yields per acre: Finally, small farms often get higher yields per acre for any given crop, simply by virtue of putting more time and care into their farming. While it is not negligible, this differential generally is less important to overall land productivity differences than the other three. ${ }^{15}$

These four effects combine to create a significant advantage, even when the political environment favors larger farmers in multiple ways. In Brazil, for example, family farms account for $40 \%$ of the total national value of production, while occupying just $30 \%$ of agricultural land area. They generate $77 \%$ of Brazil's agricultural employment, while receiving only $25 \%$ of farm credit (Pengue, 2005).

These land productivity differences can be traced above all to differences in the use of labor. As a rule, small farmers get more output by applying more labor per acre. Labor productivity output per unit labor - is often lower on small farms. But in settings where land is scarce and labor relatively abundant, land productivity is the more relevant indicator of overall efficiency.

Why do small farms use more labor per acre? Three main reasons can be advanced. The first is what economist Amartya Sen (1975a) calls the 'labor cost' explanation: working on one's own land is not the same as working for someone else. Small farmers may be willing to work on their own land even when the return (the extra product from a day's work) is less than the daily wage. For example, performing a task like irrigating the crop may only take an hour or two, but if this precludes getting work that day as a wage laborer, the small farmer may put more time into other farm tasks rather than taking the rest of the day off. Or farmers simply may prefer to be their own boss, and be willing to accept a lower 'wage' in return for the satisfaction and status this confers. In this respect, as Sen $(1975 \mathrm{~b}, 199)$ has observed, labor differs fundamentally from other inputs: workers 'are endowed with minds and with ideas and preferences,' and these can include a preference to work on their own land.

A second explanation is based on the need for supervision of hired laborers. In the absence of concern for the well-being of their employers, wage laborers have an incentive to work hard only insofar as their jobs depend on it. In agriculture, it is often difficult to tell how much effort a laborer has expended simply by looking at the field. For this reason, employers spend time and money to supervise their farm workers. If there were no incentive problem, or if supervision were costless, hired labor would be just as efficient as family labor. But if neither of these conditions holds, large landowners who rely on hired labor will use less labor per acre than owner-operated farms. ${ }^{16}$ 
A third explanation is based on the observation that local labor markets are often partitioned by natural and social boundaries into 'an archipelago of small, fragmented labor markets' (Griffin, Khan, and Ickowitz 2002, 287). In such settings, individual employers wield monopsony power - if they demand more labor, wages go up, and if they demand less, wages go down. This means they have an incentive to employ less labor than would be the case either in competitive labor markets or on owner-operated farms.

These three explanations are not mutually exclusive. In any given place, the lower cost of family labor, the supervision problem with hired labor, and local monopsony power of large landowners may all be at work, contributing in varying degrees to the phenomenon of more labor-intensive practices and higher output per acre on small farms.

\section{The limitations of markets}

This raises a further question: if small farmers are able to use land more productively than large landowners, why don't markets reallocate land to them? Assuming that farmland is worth most to those who can use it best, over time we could expect market forces to channel it to the highest bidder. Yet, in reality, land sales by large landowners to small farmers are the exception, not the rule. There are two main reasons. The first is the familiar chicken-and-egg problem: the poor need credit to buy land, but without land they lack the collateral to secure loans. The second is that in practice the distribution of land often is determined by political power rather than purchasing power. Historically, inequitable land ownership patterns rarely originated in the free play of market forces; rather they emerged through processes involving conquest, fraud, and outright force. Today political power and land rights remain fused in rural societies, each reinforcing the other. For landed elites, the value of land lies therefore not only in its agricultural productivity, but also in the power, status, and economic advantages that land ownership confers. ${ }^{17}$ Efforts to promote 'market-assisted land reform' by earmarking credit for land purchases for small farmers often founder on this stumbling block.

Nor do land rental markets provide an adequate solution. Tenancy arrangements do allow the surplus land of the rich to be combined with the surplus labor of the poor, bypassing the drawbacks of hired labor discussed above. But at the same time, tenancy creates a new set of incentive problems that again depress labor use and land productivity. The most widespread form of tenancy in many parts of the world is sharecropping, in which the landlord takes a share of the harvest (often half) as rent and the sharecropper gets the rest. As far back as the time of Adam Smith, economists have pointed out that this reduces the tenant's incentive to put labor into the land, since the tenant bears the full cost of each unit of labor but receives only a fraction of the

resulting output. ${ }^{18}$ Fixed rents avoid this problem, but leave the tenant to bear all the risks of output and price fluctuations. Moreover, tenants have no incentive to make investments that enhance the long-term productivity of the land, unless they have 'occupancy rights' that protect them from eviction. Granting such rights to tenants is itself a land reform, since it redistributes one important stick in the property-rights bundle. The landowners' fear of losing property rights is one reason that long-term land rentals are uncommon. ${ }^{19}$

Neither hired labor nor tenancy arrangements successfully resolve the inefficiencies that result from a dichotomy between the ownership of land and labor on it. By ending this dichotomy, land 
reforms can bring forth higher agricultural output as well as a more egalitarian distribution of that output. 'In most cases,' the International Fund for Agricultural Development $(2001,71)$ concludes, 'if the poor get a bigger share of asset control or benefits, efficiency and economic growth also improve.' By creating a bigger pie as well as a wider slice for the poor, land reform offers a potent strategy for reducing rural poverty. If land reform has positive spillover effects on the urban economy, too, as the East Asian experience suggests, then its contribution to poverty reduction can be even greater.

\section{Land Reform and the Environment}

What about the environmental impact of land reform? If land reform does promote laborintensive farming and higher land productivity, will this accelerate land degradation?

\section{Land use and land abuse}

The answer to this question hinges on the difference between land use and land abuse. Not all agriculture is tantamount to environmental degradation; on the contrary, sustainable farming practices can increase nature's wealth. For example, while myopic farming practices often deplete soil nutrients and cause soil erosion, sustainable farming can increase both the depth of soils and their fertility. Let us illustrate by means of two examples.

The first is from the southwestern United States. Starting in the sixteenth century, Spanish farmers began to settle the upper Rio Grande valley, in the territory that now spans northern New Mexico and southern Colorado. To irrigate the semi-arid lands, the settlers built channels called acequias that carry water from upstream to valley slopes below. This gravity-fed irrigation system transformed local landscapes into a mosaic of wetlands, cultivated fields, orchards, and riparian corridors for wildlife movement. Over the generations, the land stewardship of these Hispano farmers and their descendants has created deep and fertile soils. Anthropologist Devon Peña $(2003,169)$ describes humans as the 'keystone species' of this acequia ecosystem: without the people, many other species in the ecosystem would not survive.

The second example comes from South America's Amazon basin. Notwithstanding Amazonia's lush rainforests, most of the region's soils are nutrient-poor and subject to rapid erosion if the forest cover is removed. However, roughly $10 \%$ of Amazonia - an area roughly the size of France - has fertile soil known as terra preta do indio, the 'dark earth of the Indians'. Researchers believe that terra preta is not a random anomaly, but rather a deliberate creation of indigenous farmers who long ago practiced 'slash-and-char' agroforestry in the region. ${ }^{20} \mathrm{~A}$ noteworthy feature of terra preta is its remarkable capacity for self-regeneration, which scientists attribute to soil microorganisms. 'In a process reminiscent of dropping microorganismrich starter into plain dough to create sourdough bread,' (Mann, 2000b, p. 52) explains, 'Amazonian peoples inoculated bad soil with a transforming bacterial charge.' Today researchers are investigating whether terra preta can be used to improve soil fertility elsewhere, including in sub-Saharan Africa. ${ }^{21}$ 
These examples illustrate the fact that agriculture can add to - as well as subtract from - nature's wealth. The question, then, is what determines the balance between positive and negative effects? Why do farmers enrich the environment in some times and places, and degrade it in others? In particular, how might land reform affect this balance?

\section{Environmental advantages of small farmers}

No iron rule ensures that small farmers will invest more in natural capital, or manage their lands more sustainably, than large farmers. Outcomes in the field depend on the opportunities and incentives farmers face, and the cultural and institutional environment in which they operate. But there are four good reasons to believe that land reform not only is compatible with sustainable agriculture, but also can help to promote it:

- First, environmentally beneficial land-use practices are often more labor-intensive than environmentally costly land abuse. For example, manual weed control takes more labor than using herbicides. Integrated pest management often is more labor-intensive than simply blasting the fields with insecticides. Similarly, applying bulky organic manures takes more work than applying concentrated chemical fertilizers. Small farms have a comparative advantage in these and other labor-intensive practices for the reasons discussed above, and this translates into a comparative advantage in environment-friendly farming.

- Second, intimate knowledge of the local environment - including soils, weather, crop varieties, insects, and plant diseases - is a key input in sustainable agriculture. A dichotomy between the ownership of land and labor on it often leads to a dichotomy between decisionmaking and local knowledge. Absentee landowners, in particular, generally lack the accumulated knowledge of small-scale family farmers.

- Third, small farmers not only have greater ability to care for the land; they also have greater willingness to do so. As owners of the land, they clearly have a stronger incentive to maintain its long-term productivity than do tenant farmers or hired laborers. Apart from self-interest, the ownership of the land often instills a moral sense of duty to safeguard it. For family farmers, land is not just another input: it is an asset to be passed to future generations. ${ }^{22}$

- Finally, farmers who cultivate the land by means of their own family's labor have a much stronger incentive to worry about occupational health and safety, including exposure to toxic pesticides. The people who bear the highest costs from environmentally destructive farming practices often are those who toil in the fields. In farming as other occupations, protecting workers' health goes hand-in-hand with protecting the environment.

\section{Small farms and agricultural biodiversity}

The environmental advantages of small farmers are illustrated by their vital role in the evolution and conservation of agricultural biodiversity. The food crops on which we depend for survival are not simple gifts of nature: they are the fruits of interactions between humans and plants than began ten millennia ago when the inhabitants of Asia Minor domesticated wheat and barley. Their counterparts in south and east Asia gave us rice, an extraordinarily versatile plant that can 
survive in continuously flooded fields. In the Andean mountains early Americans evolved the potato, the world's most important root crop, and in Mesoamerica the forbearers of today's campesino farmers evolved maize from its wild relative, teosinte. With few exceptions, the centers of origin of humankind's food crops are in the global South. ${ }^{23}$

Over the millennia, the process that Charles Darwin termed 'artificial selection' has continued in the farmers' fields. At harvest time, they saved seed from those individual plants that fared best on their lands, for replanting in the next season. In this way, new varieties co-evolved to grow in diverse habitats and adapt to changing environments. This monumental process of investment in natural assets gave us the thousands of crop varieties that exist today. In terms of human wellbeing, the crop genetic diversity given to us by generations of small farmers unquestionably ranks among the most important sources of biodiversity on the planet, the storehouse from which plant breeders draw to adapt all crops to changing insect pests, plant diseases, and climatic conditions.

As a rule, it is small farmers who practice high-diversity agriculture today. In so doing, they generate a 'positive externality' by conserving crop genetic diversity in situ (in the field). Not only do different small farmers in a given locality often cultivate different varieties of the same crop, but also individual small farmers often cultivate several different varieties. Large farms, on the other hand, often sow a single variety over a large acreage. The result is an inverse relationship between farm size and varietal diversity.

One reason for this is the comparative advantage of small farms in labor-intensive farming practices. It takes more time and effort to grow multiple varieties with different sowing dates, cultivation requirements, and harvest times than to grow a single, uniform variety. Considerable labor is also needed to maintain the physical infrastructures - such as watercourses and terraces that often accompany high-diversity agriculture.

A second reason is again the importance of local knowledge. Small farmers are the repositories of wisdom about the characteristics of different crop varieties. They know which varieties grow best in what locations, which are most resistant to what pests and diseases, which are best suited to what culinary purpose. Without the farmers, it not only would be harder to sustain agricultural biodiversity, it also would be harder to know what is being sustained. In many parts of the world, women play a particularly important role in managing agricultural biodiversity and maintaining this knowledge. In the indigenous communities of the Guatemalan highlands, for example, it is often women who select the seed for the next production cycle, doing so on the basis of culinary requirements and Mayan cosmology as well as agronomic characteristics. ${ }^{24}$

There is also a historical reason why small farmers today are the main cultivators of diversity: they tend to predominate in 'marginal' agricultural environments where the spread of 'modern' crop varieties has been held in check by less favorable growing conditions. Hilly terrain, like the highlands of southern Mexico and Guatemala, is less suited to varietal monoculture and agricultural mechanization; similarly, the deeply flooded parts of the Bengal delta are unsuitable for the new short-statured, high-yielding rice varieties. Such lands have been relatively unattractive as targets for appropriation by landed elites, while at the same time having environmental conditions that favor varietal diversification. 
This is not to suggest that small farms are or should be living museums. On the contrary, a hallmark of traditional agriculture is its dynamism. Varietal selection proceeds unabated in farmers' fields, which continue to serve as 'evolutionary gardens' (Wilkes 1992, 24-26). In this evolutionary process, the dividing line between 'traditional' and 'modern' agriculture often becomes blurred. Traditional varieties co-exist with new varie ties, and cross-pollination and mutation give rise to successive generations adapted to local conditions and tastes. ${ }^{25}$ Indeed, given the dynamic character of small-scale agriculture, the 'traditional-modern' distinction is better described as a contrast between high-diversity and low-diversity agricultural ecosystems.

Nor do we mean to suggest that small farms are immune to the appeal, or threat, of varietal monoculture. Where 'high yielding varieties' (more accurately, highly fertilizer-responsive varieties) of rice and wheat are suited to the lands of small farmers, as in much of Asia, they have displaced large numbers of traditional varieties. Moreover, imported grain from industrialized countries - artificially cheapened by the ecological subsidy from high-diversity agriculture as well as monetary subsidies from Northern governments - is now displacing local production in many developing countries. Both phenomena are contributing to the erosion of crop genetic diversity.

If the environmental advantages of small farms are to translate into competitive advantages in the marketplace, a supportive policy environment is necessary. This includes policies to reward farmers for generating 'positive externalities' like the conservation of agricultural biodiversity, and policies to incorporate 'negative externalities' like pollution and soil erosion into the costs of production and the resulting output prices. ${ }^{26}$ Land reform alone does not guarantee a move toward sustainable agriculture, but it can and should be a part of the policy mix.

\section{Conclusions}

There is no single road to successful land reform. It takes different forms in different physical and human environments. Nevertheless we can identify several common ingredients in successful experiences:

- Secure rights are critical. Without them, families and communities will remain unwilling and unable to invest in land improvements, and the gains of land reform will remain vulnerable to reversal.

- Women's rights to land must be part of the mix. When land titles are vested exclusively in male 'heads-of-household,' divorce and widowhood can lead to the destitution of women and children. Moreover, women's labor and knowledge often are crucial in small-scale farming.

- The rights of indigenous communities to land, forests, water and other common property resources must be guaranteed and protected, as must their right to manage them using customary law and tradition. While property rights are crucial, no single form of property is universally the best. 
- The land distributed must be of suitable for farming and free of disputed claims by other poor people.

- When families receive land, they must not be saddled with heavy debt burdens to pay for it. This can be accomplished by limiting the amount of compensation paid to former owners.

- Small farmers need more than land if they are to make a living. They also need a supportive policy environment, including access to credit on reasonable terms, fair prices for their products, and access to infrastructure and social services.

- Policies to reward farming practices that generate environmental benefits, like the conservation of agricultural biodiversity and the protection of watersheds, can strengthen rural livelihoods and the competitive advantages of small farms.

- At the same time, policies to discourage farming practices that generate environmental costs, like the profligate use of pesticides, can further enhance the competitive advantages of small farms.

- In today's neoliberal political environment, strong grassroots movements like the MST are critical to the land reform process. Land occupations that capitalize on the legal and political space to contest property right can be a particularly effective method of pressing governments to act.

Experience shows that pro-poor land reform is possible. For example, it was done successfully in the mid- $20^{\text {th }}$ century in East Asia. And it is being done successfully today in Brazil. When done well - with genuine grassroots engagement, the redistribution of power as well as land, and a supportive social and policy environment - land reform is a powerful strategy to reduce poverty while improving environmental quality. 


\section{Endnotes}

${ }^{1}$ Adams et al. $(1999,9)$ observe: 'Land rights may include one or more of the following: rights to occupy a homestead, to use land for crops, to make permanent improvements, to bury the dead, and to graze animals, have access for gathering fuel, fruits, grass, minerals etc.; rights to transact, give, mortgage, lease, rent and bequeath areas of exclusive use; rights to exclude others from the above; rights to enforcement of legal and administrative provisions in order to protect the rights holder.' For discussion, see also Ross (1989), Schlager and Ostrom (1992), and Sterner (2003, ch. 5).

2 De Janvry, Sadoulet, and Wolford $(2001,294)$ cite the case of Chile as an 'archetypal occurrence' of land reconcentration. Among other factors, they point to the land reform beneficiaries' inadequate access to credit and inputs; their high debts incurred for land acquisition; an unfavorable macroeconomic environment for traditional crops due to trade liberalization and exchange-rate appreciation; and the greater capacity of larger farmers to participate in the fruit and vegetable export boom by making heavy capital investments with long maturation periods.

${ }^{3}$ In 1992, however,. Article 27 of the Mexican constitution was amended to allow ejidos to vote to grant individual titles to plots that can then be sold, rented, or mortgaged, a change that critics fear will open the door to greater land concentration.

${ }^{4}$ See Deere, Marchetti, and Reinhardt (1985) and Enríquez (1991, 1997) for discussion of the Nicaraguan land reform experience. A similar policy shift took place in Cuba in the 1990s, motivated by the country's economic crisis and the need for greater food self-sufficiency coupled with less reliance on petroleum-intensive technologies; see Funes (2002).

${ }^{5}$ For an account, see Abdullah (1976).

${ }^{6}$ See Schlesinger and Kinzer (1982, 54) and Sobhan (1993, 53-4).

${ }^{7}$ In a similar vein, De Janvry et al. $(2001,5)$ remark: 'Access to land is ... not sufficient to secure higher incomes. This is the case when the policy context is adverse to farm profits, competitiveness is undermined by a lack of supportive institutions, assets transferred are not valorized by complementary public goods (e.g., access roads), and investment is deterred by insecurity regarding conditions for access.'

${ }^{8}$ In principle, as noted above, such a system of use (or 'usufruct') rights can prevent land concentration and the reemergence of landlordism. In practice, however, it can leave farmers vulnerable to landgrabbing by politically powerful interests - a problem that has become evident in China in the last decade, as real estate development on the periphery of urban areas has pushed millions of farmers off the land (Yardley 2004).

${ }^{9}$ Fei, Ranis, and Kuo (1979, p. 44). For discussion, see also Campos and Root (1996, pp. 51-53). 
${ }^{10}$ An example is the Philippines, where the failure to carry out a serious postwar land reform had far-reaching consequences for the distribution of political power and the fate of economic development strategies; for discussion, see Putzel (1992), Boyce (1993), and Hutchcroft (2005).

${ }^{11}$ For more on the MST and 'and reform from below,' see Rosset (2001a, 2001b).

12 Interviews conducted on MST settlements by Rosset in 2001-2005. See also Branford and Rocha $(2002,216)$.

${ }^{13}$ For examples and discussion, see Branford and Rocha (2002, 211-239).

14 According to the 1996 agricultural census of Bangladesh, among farms of $1 / 2$ acre or less, $21 \%$ of the land is single-cropped, $67 \%$ is double-cropped, and $12 \%$ is triple-cropped. The corresponding figures for farms of 25 acres or more are 59\%, 37\%, and 4\% (Government of Bangladesh, 1999, 25).

${ }^{15}$ For extensive reviews of evidence on the size-productivity relationship, see Berry and Cline (1979), Netting (1993), Tomich, Kilby, and Johnston (1995), Binswanger, Deininger, and Feder (1995), and Rosset (1999).

${ }^{16}$ For further discussion of labor supervision as an explanation for the inverse relation between farm size and labor use, see Sen (1981) and Boyce (1987, 39-40).

17 These economic advantages include access to subsidized credit, favorable tax treatment of agricultural incomes, and landholding as a hedge against inflation. For discussion, see Binswanger at al. (1995, 2710-11).

${ }^{18}$ See Smith (1904 [1776], 366-7). For discussion of the efficiency impacts of sharecropping, see also Boyce (1987, 41-44, 213-220).

19 'The history of land reform,' Binswanger et al. (1995, 2694) remark, 'shows that long-term rental of entire farms often implies a high risk of loss of land to tenants.'

${ }^{20}$ See Mann (2002a). Brookfield (2001, pp. 96-97) discusses this and other examples of 'manufactured soils. See also Amanor (in this volume).

${ }^{21}$ For discussion, see Mann (2005).

${ }^{22}$ For further discussion, see Rosset (1999, 2001a).

${ }^{23}$ For discussions of the origins of these and other crop plants, see MacNeish (1992), Harlan (1995), Smartt and Simmonds (1995), and Smith (1995).

${ }^{24}$ FAO/IPGRI (2002, 22, 39-40). See also Howard (2003). 
${ }^{25}$ For examples, see Biggs (1980), Brush (1995, 2003), and Bellon, Pham, and Jackson (1997).

${ }^{26}$ For further discussion, see Mann (2004), Boyce (2005), and Rosa et al. (in this volume). 


\section{References}

Abdullah, Abu (1976) 'Land Reform and Agrarian Change in Bangladesh,' Bangladesh Development Studies 4(1): 67-114.

Acevedo, Carlos (1996) 'Structural Adjustment, the Agricultural Sector, and the Peace Process,' in James K. Boyce, ed., Economic Policy for Building Peace: The Lessons of El Salvador. Boulder: Lynne Rienner, pp. 209-231.

Adams, Martin, Ben Cousins and Siyabulela Manona (1999) 'Land Tenure and Economic Development in Rural South Africa: Constraints and Opportunities.' London: Overseas Development Institute, Working Paper No.125, December 1999. Available at: http://www.odi.org.uk/publications/working_papers/wp125.pdf.

Bellon, M.R., J.-L. Pham, and M.T. Jackson (1997) 'Genetic Conservation: A Role for Rice Farmers,' in N. Maxted, B. Ford-Lloyd, and J.G. Hawkes, eds., Plant Genetic Conservation: The In Situ Approach. London: Chapman \& Hall, pp. 263-289.

Berry, R. Albert and William R. Cline (1979) Agrarian Structure and Productivity in Developing Countries. Baltimore : Johns Hopkins University Press.

Biggs, Stephen D. (1980) 'Informal R\&D,' Ceres (Rome: Food and Agriculture Organization) 13(4): 23-26.

Binswanger, Hans P., Klaus Deininger, and Gershon Feder (1995) 'Power, Distortions, Revolt and Reform in Agricultural Land Relations,' in J. Behrman and T.N. Srinivasan, eds., Handbook of Development Economics, Volume III. Amsterdam: Elsevier Science, pp. 2559-2771.

Boyce, James K. (1987) Agrarian Impasse in Bengal: Institutional Constraints to Technological Change. Oxford: Oxford University Press.

Boyce, James K. (1993) The Philippines: The Political Economy of Growth and Impoverishment in the Marcos Era. London: Macmillan and Honolulu: University of Hawaii Press.

Boyce, James K. (2005) 'A Future for Small Farms? Biodiversity and Sustainable Agriculture,' in James K. Boyce, Stephen Cullenberg, Prasanta Pattanaik, and Robert Pollin, eds., Human Development in the Age of Globalization (forthcoming from Edward Elgar).

Branford, Sue and Jan Rocha (2002) Cutting the Wire: The Story of the Landless Movement in Brazil. London: Latin American Bureau.

Brookfield, Harold (2001) Exploring Agrodiversity. New York: Columbia University Press.

Brush, Stephen B. (2003) 'The Lighthouse and the Potato: Internalizing the Value of Crop Genetic Diversity,' in James K. Boyce and Barry G. Shelley, eds., Natural Assets:

Democratizing Environmental Ownership. Washington, D.C.: Island Press, pp. 187-205. 
Brush, Stephen B. (1995) 'In Situ Conservation of Landraces in Centers of Crop Diversity,' Crop Science 35: 346-354.

Campos, Jose Edgardo and Hilton L. Root (1996) The Key to the Asian Miracle: Making Shared Growth Credible. Washington, DC: Brookings Institution.

Deere, Carmen Diana (2003) 'Women's Land Rights and Rural Social Movements in the Brazilian Agrarian Reform,' Journal of Agrarian Change 3(1/2): 257-288.

Deere, Carmen Diana, and Magdalena León (2001) Empowering Women: Land and Property Rights in Latin America. Pittsburgh, PA: University of Pittsburgh Press.

Deere, Carmen Diana, Peter Marchetti, and Nola Reinhardt (1985) "The Peasantry and the Development of Sandinista Agrarian Policy, 1979-1984." Latin American Research Review 20(3): 75-109.

De Janvry, Alain, Gustavo Cordillo, Jean-Philippe Platteau, and Elisabeth Sadoulet (2001) 'The Changing Role of the State in Latin American Land Reforms,' in Alain De Janvry et al., eds., Access to Land, Rural Poverty, and Public Action. Oxford: Oxford University Press, pp. 279-303.

De Janvry, Alain, Elisabeth Sadoulet, and Wendy Wolford (2001) 'Access to Land and Land Policy Reforms,' in Alain De Janvry et al., eds., Access to Land, Rural Poverty, and Public Action. Oxford: Oxford University Press, pp. 1-26.

Dore, Ronald P. (1959) Land Reform in Japan. London: Oxford University Press.

Enríquez, Laura J. (1991) Harvesting Change: Labor and Agrarian Reform in Nicaragua, 19791990. Chapel Hill: University of North Carolina Press.

Enríquez, Laura J. (1997) Agrarian Reform and Class Consciousness in Nicaragua. Gainesville: University Press of Florida.

Fei, J.C.H., G. Ranis, and S. Kuo (1979) Growth with Equity: The Taiwan Case. New York: Oxford University Press.

Food and Agriculture Organization of the United Nations (FAO) (2004) The State of Food Insecurity in the World 2004. Rome: FAO. Available at: ftp://ftp.fao.org/docrep/fao/007/y5650e/y5650e00.pdf.

Food and Agriculture Organization of the United Nations (FAO) and International Plant Genetic Resources Institute (IPGRI) (2002) The Role of Women in the Conservation of the Genetic Resources of Maize. Rome: FAO/IPGRI. 
Funes, Fernando, Luis García, Martin Bourque, Nilda Pérez, and Peter Rosset, eds. (2002) Sustainable Agriculture and Resistance: Transforming Food Production in Cuba. Oakland, CA: Food First.

Government of Bangladesh (1999) Census of Agriculture, 1996: Agricultural Sample Survey 1997, Volume 2. Dhaka: Bangladesh Bureau of Statistics.

Griffin, Keith, Azizur Rahman Khan, and Amy Ickowitz (2002) 'Poverty and the Distribution of Land,' Journal of Agrarian Change 2(3): 279-330.

Hammond, John L. (1999) 'Law and Disorder: The Brazilian Landless Farmworker's Movement,' Bulletin of Latin American Research 18(4): 469-489.

Harlan, Jack R. (1995) The Living Fields: Our Agricultural Heritage. Cambridge: Cambridge University Press.

Howard, Patricia L., ed. (2003) Women \& Plants: Gender Relations in Biodiversity Management \& Conservation. London: Zed Books.

Hutchcroft, Paul (2005) The Power of Patronage: Capital and Countryside in the TwentiethCentury Philippines. Cambridge: Cambridge University Press [forthcoming].

International Fund for Agricultural Development (IFAD) (2001) Rural Poverty Report 2001 - The Challenge of Ending Rural Poverty. Rome: IFAD. Available at: http://www.ifad.org/poverty.

Jang, Sang-Hwan (2004) 'Land Reform and Capitalist Development in Korea,' paper presented at the Economic History \& Development Workshop, University of Massachusetts, Amherst, May.

Ladejinsky, Wolf (1977) 'Land Reform,' in Louis J. Walinsky, ed., Land Reform as Unfinished Business: The Selected Papers of Wolf Ladejinsky. New York: Oxford University Press, pp. 354366.

MacNeish, Richard S. (1992) The Origins of Agriculture and Settled Life. Norman: University of Oklahoma Press.

Mann, Charles (2002a) ‘The Real Dirt on Rainforest Fertility,' Science 297: 920-923.

Mann, Charles (2002b) '1491,' Atlantic Monthly, March: 41-53.

Martins, Monica (2004) 'Aprendendo a Participar,' in Monica Dias Martins, ed., O Banco Mundial ea Terra: Ofensiva e Resistência na América Latina, África e Ásia. Sao Paulo: Viramundo, pp. 6174.

Meisner, Maurice (1986) Mao's China and After: A History of the People's Republic. New York: Free Press. 
Mann, Charles (2005) [piece on soils] forthcoming in National Geographic.

Netting, Robert M. (1993) Smallholders, Householders : Farm families and the ecology of intensive, sustainable agriculture. Stanford: Stanford University Press.

Pengue, Walter (2005) 'Agricultura industrial y agricultura familiar en el Mercosur: El pez grande se come al chico... siempre?' Le Monde Diplomatique, Edición Cono Sur 71:7-9.

Putzel, James (1992) A Captive Land: The Politics of Agrarian Reform in the Philippines. London: Catholic Institute for International Relations and New York: Monthly Review Press.

Rodrik, Dani (1995) 'Getting Interventions Right: How South Korea and Taiwan Grew Rich,' Economic Policy 20: 55-107

Ross, Thomas (1989) “Metaphor and Paradox.” Georgia Law Review 23: 1053-1084.

Rosset, Peter (1999) 'The Multiple Functions and Benefits of Small Farm Agriculture in the Context of Global Trade Negotiations.' Oakland, CA: Institute for Food and Development Policy, Food First Policy Brief No. 4.

http://www.foodfirst.org/media/press/1999/smfarmsp.html

Rosset, Peter (2001a) 'Access To Land: Land Reform and Security of Tenure.' Paper prepared for the FAO World Food Summit Five Years Later. http://www.landaction.org/display.php?article=179

Rosset, Peter (2001b) 'Tides Shift on Agarian Reform: New Movements Show the Way.' Oakland, CA: Institute for Food and Development Policy, Food First Backgrounder 7(1).

Schlager, Edella and Elinor Ostrom (1992) 'Property-Rights Regimes and Natural Resources: A Conceptual Analysis.' Land Economics. 68(3): 249-262.

Schlesinger, Stephen and Stephen Kinzer (1982) Bitter Fruit: The Untold Story of the American Coup in Guatemala. Garden City, NY: Doubleday.

Sen, Abhijit (1981) 'Market Failure and Control of Labour Power: Towards an Explanation of Structure and Change in Indian Agriculture,' Cambridge Journal of Economics 5(3): 201-228.

Sen, Amartya (1975a) Employment, Technology and Development. Oxford: Oxford University Press.

Sen, Amartya (1975b) 'The Concept of Efficiency,' in M. Parkin and A. Nobay, eds., Contemporary Issues in Economics. Manchester: Manchester University Press, pp. 196-210.

Shin, Gi-Wook (1998) "Agrarian Conflict and the Origins of Korean Capitalism," American Journal of Sociology 103(5): 1309-1351. 
Smartt, J. and Simmonds, N.W., eds. (1995) Evolution of Crop Plants. $2^{\text {nd }}$ edn. Harlow: Longman Scientific \& Technical.

Smil, Vaclav (1999) “China’s Great Famine: 40 Years Later,' British Medical Journal 319(1825 December): 1619-1621.

Smith, Adam (1904 [1776]) An Inquiry into the Nature and Causes of the Wealth of Nations (Cannan edn.). London: Methuen.

Smith, Bruce D. (1995) The Emergence of Agriculture. New York: Scientific American Library.

Sobhan, Rehman (1993) Agrarian Reform and Social Transformation: Preconditions for Development; London: Zed Books.

Stédile, João Pedro (2004) Personal communication (MST, Brazil).

Sterner, Thomas (2003) Policy Instruments for Environmental and Natural Resource Management. Washington, DC: Resources for the Future.

Tomich, Thomas, Peter Kilby, and Bruce F. Johnston (1995) Transforming Agrarian Economies: Opportunities Seized, Opportunities Missed. Ithaca: Cornell University Press.

Wilkes, Garrison (1992) Strategies for Sustaining Crop Germplasm Preservation, Enhancement, and Use. Consultative Group on International Agricultural Research, Washington, D.C.

Wright, Angus and Wendy Wolford (2003) To Inherit the Earth: The Landless Movement and the Struggle for a New Brazil. Oakland: Food First Books.

Yardley, Jim (2004) 'In Rural China, Unrest Over Land Seizures,' International Herald Tribune, 9 December, p. 2. 